\title{
STUDY OF ORGANIZATIONAL COMMITMENT IN THE CONTEXT OF LEADERSHIP STYLES AND REASONS OF EMPLOYEE SILENCE
}

\begin{abstract}
The aim of this study is to determine the connections between leadership styles, the reasons of employee silence and organizational commitment. Besides, another goal of this research is to obtain the reasons of the effects of employee silence on relationship between leadership styles and organizational commitment. For this purpose, scales were applied by searching literature related to 758 people. The survey consists of various firms operating in manufacturing and service industry, and data have been analyzed through the SPSS 15 statistical packet program. Established data analyzed with factor analysis, correlation, regression and cronbach alpha methods. Hypotheses concerning the relationship between leadership styles and organizational commitment between the reasons of employee silence and organizational commitment and lastly, reasons of the role of employee silence as a mediator variable between organizational commitment and leadership styles were tested and the relation has been considered as significant. Established diagnosis discussed in the context of relevant literature.
\end{abstract}

Keywords: Leadership Styles, Reasons of Employee Silence, Organizational Commitment.

\section{INTRODUCTION}

Leadership and organization works have been a focal point of many disciplines in recent years. Nowadays, there are a great many attempts to determine the place of organizations in the post modern period as well as to identify the leaders of organizations again. Seeking new leaders require a specific study of employees once more in this new period. The expectation in all periods is the effective efficiency of the employee. The employee's use of his/her skill and knowledge for the organization are also closely related to the organizational commitment. This study examines organization commitment within the deepening structure of the concept of organizational commitment under the headings of "Affective Commitment to Organization" and "Normative Commitment to Organization".

Many studies in the literature are established on the variables that are expected to have positive relation with organizational commitment. However, today's business world does not appear to be bed of roses. When things start to go bad for us, some try to solve the problem while others remain silent. However, remaining silence occurs more often when bad things happen in a work environment that we manage or that we are managed in. Therefore, business administration literature has focused on the concept of employee silence in the last 20 years.

In an environment where problems are so tense, the experiences of an employee may push him/her to a spiral of silence. Some problems in the way of management or in the organization culture may keep him/her within the same spiral. An environment where the employee sees a risk in expressing views or where there is a perception that relations will be broken may push him/her to silence and he/she may experience fear of isolation in the organization. The focus of this study is to determine how the organizational commitment will be affected in an environment where the employee refrains from expressing views and opinions.

\section{LITERATURE REVIEW}

\section{LEADERSHIP STYLE}

Various leadership styles were studied by the researchers within the framework of organization effectiveness and the full range leadership model suggested by Bass was considered to be the most modern theory among these styles (Hambley etal. 2007: 2; Bodla and Nawaz, 2010: 209; Giri and Santra, 2010: 85-86). This model focuses on three leadership styles which are Transformational Leadership dealing with the employee personally and trying to convince employees to achieve hard tasks by revealing vision to organization members and starting transformation process in the organization; Transactional Leadership that opts to work and make others work by 
improving on-going activities of employees or by rendering these activities to make them more effective and efficient, explains what the employees have to achieve and rewards the employees when desired results are obtained; Laissez-faire Leadership that does not claim power and allows the right to use power totally to followers (Bass, 1990; Gordon, J.R. 1993; Bass and Avolio 1994; Glad and Blanton, 1997; Pillai etal. 1999; Greenberg and Baron, 2000; Sosik and Godshalk, 2000, Eren, 2001; Lather etal., 2009; Giri and Santra, 2010)

\section{REASONS OF EMPLOYEE SILENCE}

Silence in organizations is defined as such that employees consciously withhold their opinions and thoughts with respect to technical and/or behavioural issues related to the improvement and development in work or work place (Çakıc1, 2007:149). Employee silence is the withholding of any form of genuine expression about the behaviour of individuals in an organization (Pinder and Harlos, 2001:334). It is meaningful and necessary to know why and how employees are silent, issues which they refrain to speak about most, who they share the relevant issue or problem with, how they determined whom to speak to and whom to remain silence to (Milliken etal., 2003:1454). The reasons of employee silence can be listed as the Past Experiences as the cause of learning to remain silence in their talks to their colleagues and in their observations (Milliken etal., 2003:1468); Reasons Caused by Management and Organization as the cause of prevention of speaking by employees on technical and structural issues, belief in some organizations that there is no need for oppositions on administrative privileges and common policies, intolerance on open talks of issues (Morrison and Milliken, 2000:706); Considering Speaking as a Risk as the cause of belief of employees that it is a risk to speak openly and to involve in discussions on organization although they are confident in themselves (Premeaux and Bedeian, 2003:1537); Fear of Damaging Relations as the cause of the fact that employees fear that they would lose their jobs, couldn't be promoter, face preventions when they talk and that their relation would be damaged if they talk about a negative issue about their colleagues (Milliken etal., 2003:1462, Vakola and Bouradas, 2005:441); Isolation Fear as the cause of their thinking that speaking frankly on problems and concerns would be perceived negatively by managers, thus trust and respect to employee would be reduced, social ties within an organization would be weakened with negative effects on employees (Milliken etal., 2003: 1469-1472).

\section{ORGANIZATIONAL COMMITMENT}

Commitment is a whole consisting of elements like the will to remain as a member of organization, to work hard for the organization and the belief in the objectives and values of an organization (Dubin etal., 1975), (Steers, 1977). According to Allen and Meyer (1990); commitment studies of Mowday in 1982 suggested that the commitment psychology can be measured and conceptualized in various ways and divided it into 3 groups. These are emotional commitment, perceived cost and obligation. In 1984, Meyer and Allen divided organization commitment into two: affective commitment and continuance commitment. In the study of 1990, they developed a triple model and classified it as affective, normative and continuance commitment (Meyer etal. 2002). However, our study does not cover the continuance commitment which was defined by some researchers as "employees remain as members of organization as required by circumstances due to the scarcity of perceived job alternatives and keep minimum level of performance to remain in the organization which is an undesired type of commitment by these organizations" (Allen and Meyer, 1990; Meyer and Allen, 1997; Meyer etal. 2002). An employee with affective commitment considers himself/herself as a part of the organization and therefore, the organization will have great meaning and value to him/her. He/ she will have great pride and satisfaction for being a member of organization (Allen and Meyer, 1990; Meyer and Herscovitch, 2001). Affective commitment is a behavioural phenomenon with respect to personality qualities and work related factors. It is based on the voluntariness of employees to support organizational goals (Mir etal., 2002). Normative Commitment is stated as commitment created by the objective of being useful to the organization with a feeling of indebtness as a result of general gainings or loyalty to employer created by the existence of social factor based experiences and convenient working environment (Herscovitch and Meyer, 2002). Some of the studies in the literature on organizational commitment provided details to the scopes of studies and determined that the individual may also be committed to their superiors, organization, duties and units (Becker and Billings, 1993; Hackett, Lapierre and Hausdorf, 2001; Wasti and Can, 2008). Attitude affecting the formation of affective commitment can be significantly affected by colleagues, specific characteristics of the work and perceptions of individual with respect to the behaviour of the organization to the individual (Mathieu and Zajac 1990). According to what is quoted by Wasti and Can (2007) from Bishop and Scott (2000); employees develop different commitments to remote organization, to the superior representing the organization and to closer colleagues (Wasti and Can, 
2007). Employees, considering the organization as a whole, conceive of the organization further from themselves than the colleagues and managers (Wasti and Can, 2008). This study examines the organization commitment to an organization within the deepening structure of the organization commitment concept under the headings of "Affective Commitment to Organization" and "Normative Commitment to Organization"

\section{The relation between Leadership Styles and Organizational Commitment}

Sub dimensions of Leadership Styles and Organizational Commitment have been dealt with different studies at different times (Lok and Crawford, 1999: 365-366). However, the number of studies in the literature dealing with the two variables at the same time is limited. Some studies showed that Leadership Style is significantly related with Organizational Commitment and increased commitment. A strong correlation was seen between the two variables. It was revealed that the strong vision, goal and values possessed by leaders increased organizational commitment and sensitivity of leaders against the needs of employees have positive impact on Organizational Commitment (Rowden,2000; Dick and Mctcalfe, 2001; Loke, 2001). Another study showed that employees having a good relationship with managers are more committed to work than those with fewer relations (Liao, Hu and Chung, 2009).

This study deals with the Organizational Commitment variable for further scrutiny and links organizational commitment of an individual to his affective and normative commitment to the organization based on the approach that analyzes organizational commitment by focusing on the superiors, organizations, tasks and units of individuals. According to Wasti and Can (2007), employees feel themselves distant from the organization than the manager. A study of Zehir etal (2010) revealed that, among leadership styles, sub dimensions of Transformational Leadership and Laissez-faire Leadership have positive relation with the Organizational Commitment to superior while Transactional Leadership has no significant relation with the Organizational Commitment to superior (Zehir, Şehitoğlu and Erdoğan, 2010). No study was found in the literature between the Leadership Styles and Organizational Commitment to the organization itself. This study focuses on the levels of commitment to the organization itself which is believed to be distant from employees rather than to the superior which is believed to be closer to employees. In this sense, the first hypothesis of the study has been established as follows:

H1: There is significant relation between Leadership Styles and Organizational Commitment

H1a: There is significant relation between Leadership Styles and Affective Commitment to Organization

H1b: There is significant relation between Leadership Styles and Normative Commitment to Organization

\section{Relation between the Reasons of Employee Silence and Organizational Commitment}

Upon examining few number of studies dealing with the relation between organizational commitment and employee silence, it is seen that organizational commitment is addressed as a result of employee silence (Morrison and Milliken, 2000; Vakola and Bouradas, 2005; Amah and Okafor, 2008). According to Dimitras and Vakola (2003), there is a negative relation between employee silence and organizational commitment (Dimitras and Vakola, 2003). In another study, it is stated that employee silence can cause lower organizational commitment (Morrison and Milliken, 2000). However, another study states that employee silence might have a two-way relation with organizational commitment and they might be both the cause and result of each other (Vakola and Bouradas, 2005). No study was found in the literature on the Reasons of Employee Silence and Organizational Commitment to the organization itself. This study focuses on the levels of commitment to the organization itself within the framework of Affective Commitment and Normative Commitment to Organization. The second hypothesis of the study has been established as follows by suggesting that the reasons of silence of an employee might one think about the place in the future of the organization.

H2: There is significant relation between Reasons of Employee Silence Leadership Styles and Organizational Commitment

H2a: There is significant relation between Reasons of Employee Silence and Affective Commitment to Organization 
$\mathrm{H} 2 \mathrm{~b}$ : There is significant relation between Reasons of Employee Silence and Normative Commitment to Organization

This study aims to review Organizational Commitment within the context of Organizational Commitment, Leadership Styles and Employee Silence. There is no study in the literature within this scope. Transformative Leaders try to convince employees that they can achieve hard tasks and while dealing personally with employees, Transactional Leaders prefer making the employees work, explain what they have to achieve and reward employees when desired results are achieved. Laissez-faire Leaders leaves the right to use power totally to subordinates. This study focuses on what the relation and significance level of the affective and normative commitment of an employee to organization will be, taking into consideration the trust issue that the individual may have with superior, suspicion of isolation from organization, concerns about Breaking Relations, fear to be regarded as a relatively complaining person and the belief that managers would not listen to the ideas of an individual working with this type of leaders. Addressing an effective leadership style together with the reasons of employee silence, it is believed that the explanation level of organizational commitment would increase. In this sense, the third and final hypothesis of the study has been established as follows:

H3: Leadership Styles are related to Organizational Commitment together with the Reasons of Employee Silence

\section{METHOD}

This study is a descriptive study conducted according to review model. This study attempts to determine the relation between Leadership Styles, Reasons of Employee Silence and Organizational Commitment. As shown in Figure 1, the relation among variables was tested.

\section{Figure 1: Research Model}

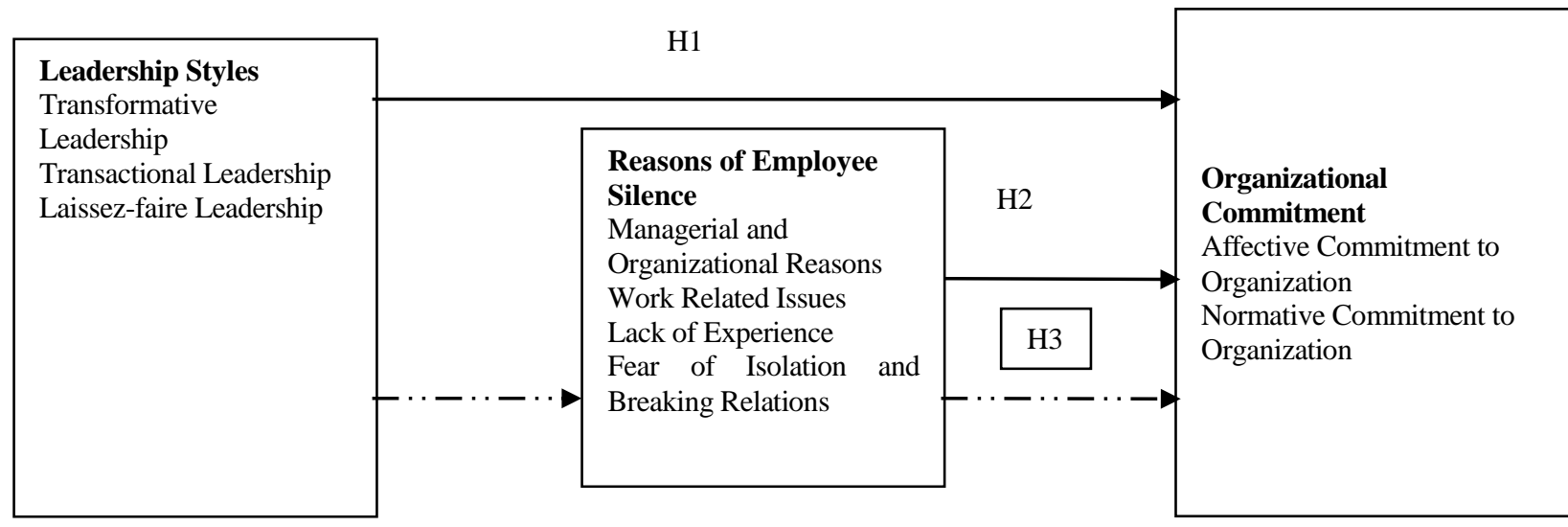

\section{Sampling}

The sample of our survey based study is the employees working in the fields of health, banking - finance, education, manufacture and other services (Communication, Hotels, Consultancy, Logistics) provided in the provinces of Istanbul and Kocaeli. 758 surveys were analyzed under the study. Data were gathered by meeting with the people face-to-face or by email. The respondents were predominantly males (79\%), females amount to (21\%). The median age group of the respondent was 25 to 45 years $(52,6 \%)$, followed by the age group 17 to 24 (18.4\%) and 45-older (29\%). More than half of the respondents who answered the question indicated education as university $(58 \%)$.

\section{Data Collection Tools}

Among the scales used in the study, those related to Leadership Styles have been formed through referring the study of Bass and Stogdill (1990), those related to the Reasons of Employee Silence are created by benefitting from the study of Çakıcı and Çakıcı (2007) and the questions related to Organizational Commitment are creating by using the question forms developed by Meyer, Barak and Vandenberghe (1996) and translated to Turkish by Wasti and Can (2007). Question Form has been arranged according to the 5 point Likert scale. 
As a result of the factory analysis on the data obtained in this study, "Leadership Styles" Scale was found to be consisting of sub scales that are Transformative Leadership, Transactional Leadership and Laissez-faire Leadership. Only the 4 items within the sub dimension of Transactional Leadership were removed from the scale as they had similar values in sub dimensions and factor analysis was repeated. In the end of analysis, KMO coefficient was found to be .939 and revealed variance was found to be $56 \%$. It was seen that the sub scale of Transformative Leadership consisted of 20 items in which the factor loads of the items varied between .581 and .782, and the alpha reliability coefficient was .683. I also found that the factor loads of the items included in the sub scale of Transactional Leadership determined to be consisting of 4 items varied between .653 and .862 and that the cronbach alpha reliability coefficient was .808. Subscale of Laissez-faire Leadership consists of five items. It was found that the factor loads of the items in this sub scale varied between .740 and .796 and that the cronbach alpha reliability coefficient was .850 .

The original of "Employee Silence Reasons" Scale developed by Çakıcı\&Çakıcı (2007) based on literature includes 5 sub dimensions. Factor analysis showed that the scale has a 4 factor structure. 1 item in the sub dimension of Work Related Issues was removed from the scale as it had very close values in sub dimensions and factor analysis was removed. Accordingly, the first factor was called as "Managerial and Organizational Reasons", second factor as "Work Related Issues", third factor as "Lack of Experience" and fourth factor as "Fear of Isolation and Breaking Relations". Sub dimensions of Fear of Isolation and Fear of Breaking Relations were not divided in the factor analysis within the scope of this study although they are separate sub dimensions in the original of the scale.

As a result of the repeated factor analysis, KMO coefficient was found to be .967 and revealed variance was found to be $64.7 \%$. It was seen that the sub dimension of Managerial and Organizational Reasons consisting of 13 items had factor loads between .520 and .773 , had a cronbach alpha reliability coefficient of .845 , factor loads of the items included in the sub dimension of Work Related Issues consisting of 4 items varied between .522 and .762 , cronbach alpha coefficient was .917, that the factor loads of "Lack of Experience" sub dimension consisting of 4 items varied between .521 and .807 and cronbach alpha reliability coefficient was .615 , that the factor loads of "Fear of Isolation and Breaking Relations" sub dimension consisting of 7 items varied between .666 and .750 and cronbach alpha reliability coefficient was .821 .

As a result of the factor analysis conducted on the obtained data, it was found that the "Organizational Commitment" Scale made of the question form called "Commitment Focuses" consisted of the sub scales of Affective Commitment to Organization and Normative Commitment to Organization. 3 items in the sub dimension of Affective Commitment to Organization and 1 item in the sub dimension of Normative Commitment to Organization had very close values and were removed from the scale. Then the factor analysis was repeated. As a result of the analysis, KMO coefficient was found to be .852 , revealed variance was found to be $65.6 \%$. It was found that the sub scale of Affective Commitment to Organization consisted of 2 items, that the factor loads of items varied between .854 and .855 and that the cronbach alpha reliability was .683. It was found that the factor loads of 6 items in the sub scale of Normative Commitment to Organization varied between .583 and .877 and that the cronbach alpha coefficient was .808 .

Considering the data obtained as a result of the validity and reliability works, it is believed that there is no problem in using the scales.

\section{Data Analysis}

Data collected within the scope of the study were analyzed through using the SPSS 15.00 program. Factor analysis, Pearson moments multiplication correlation, cronbach alpha, regression analysis were used on data to determine the relation between the variables during the process of the study. Thanks to the tested hypotheses, the intermediary effect of the variable Reasons of Employee Silence between the Leadership Styles and Organizational Commitment was tested. According to Frazier etal. (2004:125-126), intermediary effect can be determined by conducting regression analyses among three variables. First, a regression analysis was done between the Leadership Styles (independent variable) and Organizational Commitment. As a result of these two analyses, relation between variables was found to be significant. Finally, when the Leadership Styles (independent variable) were included in the model together with the Reasons of Employee Silence (intermediary variable), the contribution of Leadership Styles among these variables explaining Organizational Commitment (dependent variable) was reduced and the contribution of Reasons of Employee Silence was increased. This is a desired situation and therefore, it was found that Reasons for 
Employee Licence had an intermediary effect in explaining the relation between the Leadership Styles and Organizational Commitment.

\section{FINDINGS}

Table 2 includes the correlations between the variables of Leadership Styles, Reasons of Employee Silence and Organizational Commitment.

\section{Table 2. Correlations between the variables of Leadership Styles, Reasons of Employee Silence and Organizational Commitment}

\begin{tabular}{|c|c|c|c|c|c|c|c|c|c|c|}
\hline Variable & $\begin{array}{l}\text { Or } \\
t\end{array}$ & Ss & 1 & 2 & 3 & 4 & 5 & 6 & 7 & 8 \\
\hline $\begin{array}{l}\text { Transformative } \\
\text { Leadership (1) }\end{array}$ & $\begin{array}{l}3 \\
49\end{array}$ & $\begin{array}{l}, 8 \\
6\end{array}$ & & & & & & & & \\
\hline $\begin{array}{l}\text { Transactional } \\
\text { Leadership (2) }\end{array}$ & $\begin{array}{l}3, \\
31\end{array}$ & $\begin{array}{l}9 \\
1\end{array}$ &, $155^{* *}$ & & & & & & & \\
\hline $\begin{array}{l}\text { Laissez-faire } \\
\text { Leadership (3) }\end{array}$ & $\begin{array}{l}2, \\
33\end{array}$ & $\begin{array}{l}9 \\
6\end{array}$ & - &, $112^{* *}$ & & & & & & \\
\hline $\begin{array}{l}\text { Managerial and } \\
\text { Organizational Reasons } \\
\text { (4) }\end{array}$ & $\begin{array}{l}2, \\
65\end{array}$ & $\begin{array}{l}9 \\
9\end{array}$ & $-511^{* *}$ &, $158^{* * *}$ &, $583^{* *}$ & & & & & \\
\hline $\begin{array}{l}\text { Work Related Issues } \\
\text { (5) }\end{array}$ & $\begin{array}{l}2, \\
58\end{array}$ & $\begin{array}{l}1, \\
09\end{array}$ & $-346^{* *}$ &, $111^{* *}$ &, $463^{* *}$ &, $741^{* *}$ & & & & \\
\hline Lack of Experience (6) & $\begin{array}{l}2, \\
25\end{array}$ & $\begin{array}{l}9 \\
1\end{array}$ & $-125^{* *}$ & ,040 &, $391^{* *}$ &, $468^{* *}$ &, $465^{* *}$ & & & \\
\hline $\begin{array}{l}\text { Fear of Isolation and } \\
\text { Breaking Relations (7) }\end{array}$ & $\begin{array}{l}2, \\
52\end{array}$ & $\begin{array}{l}, 9 \\
5\end{array}$ & $-319^{* *}$ &, $132^{* *}$ &, $483^{* *}$ &, $686^{* *}$ &, $742^{* *}$ &, $554^{* *}$ & & \\
\hline $\begin{array}{l}\text { Affective Commitment } \\
\text { to Organization (8) }\end{array}$ & $\begin{array}{l}3 \\
20\end{array}$ & $\begin{array}{l}1, \\
07\end{array}$ &, $111^{* *}$ &,- 037 &,$- 276^{* *}$ & , $297^{* *}$ &, $269^{* *}$ & , $272^{* *}$ & - $298^{*}$ & \\
\hline $\begin{array}{l}\text { Normative } \\
\text { Commitment to } \\
\text { Organization (9) }\end{array}$ & $\begin{array}{l}2 \\
92\end{array}$ & $\begin{array}{l}1, \\
02\end{array}$ &, $293^{* *}$ &, 046 &, 004 &,- 070 &, 005 &, $120^{* *}$ &, 030 & ,019 \\
\hline
\end{tabular}

$* * \mathrm{p}<0.01$

When Table 2 is studied, the lowest relation was found between the Laissez-faire Leadership and Normative Commitment to Organization ( $\mathrm{r}=.004)$, and the highest relation was found between the Work Related Issues and Fear of Isolation and Breaking Relations ( $\mathrm{r}=.742)$.

In order to determine whether the Leadership Styles variable explains the Organizational Commitment variable directly and through the Reasons of Employee Silence, three different regression models were tested. The first model deals with whether the Leadership Style variable is correlated with the Organizational Commitment variable. The second model deals whether the Reasons of Employee Silence variable is correlated with the Organizational Commitment variable. Finally, the third model looks into whether the variables of Leadership Style and Reasons of Employee Silence are correlated with the Organization Commitment variable. Table 3 includes the findings of the regression analysis result regarding the first model. 
Table 3. Results of the Regression Analysis for the Relation between the Leadership Style and Organizational Commitment

\begin{tabular}{|l|l|ll}
\hline \multicolumn{2}{l}{} & Dependent Variable \\
\hline \multicolumn{2}{l}{} & Organizational Commitment \\
\hline \multirow{2}{*}{ Independent Variable } & Transformative Leadership &, 006 & Affective Commitment \\
to Organization & $\begin{array}{l}\text { Normative Commitment } \\
\text { to Organization }\end{array}$ \\
\hline \multirow{2}{*}{ Leadership Styles } & Transactional Leadership &,- 008 &, $353^{* * *}$ \\
\cline { 2 - 5 } & Laissez-faire Leadership &,$- 272 * * *$ &,- 025 \\
\hline R & &, 276 &, 321 \\
\hline R & &, 076 &, 103 \\
\hline F & & 20,704 & 28,817 \\
\hline Sig & & 0,000 & 0,000 \\
\hline
\end{tabular}

$* * * \mathrm{p}<0.001 ; * * \mathrm{p}<0.01 ; * \mathrm{p}<0.05$

When Table 3 is examined, a significant relation is found between the Laissez-faire Leadership sub dimensions of Leadership Styles and Affective Commitment to Organization ( $R=, 276, R 2=, 076, F=20,704, p<.001)$. There was no significant relation between Transformative Leadership and Affective Commitment to Organization $(\beta=, 006)$, no significant relation between Transactional Leadership and Affective Commitment to Organization $(\beta=-, 008)$, a negatively significant relation between the Laissez-faire Leadership and Affective Commitment to Organization $(\beta=-, 272 * * *)$. Also, when the results of the analysis were taken into consideration, it can be said that the Leadership Styles variable explains $10 \%$ of the Normative Commitment to Organization. As there is a significant relation between Leadership Styles and Affective Commitment to Organization, H1a appears to be accepted.

When Table 3 is examined, a significant relation is found between the Transformative Leadership and Laissezfaire Leadership sub dimensions of Leadership Styles and Normative Commitment to Organization ( $\mathrm{R}=, 321$, $\mathrm{R} 2=, 103, \mathrm{~F}=28,817, \mathrm{p}<.001)$. The relation between Transformative Leadership and Normative Commitment to Organization was found to be positively significant $\left(\beta=, 353^{* * *}\right)$. The relation between Transactional Leadership and Normative Commitment to Organization was not found to be significant $(\beta=-, 025)$ and the relation between Laissez-faire Leadership and Normative Commitment to Organization was found to be positively significant $(\beta=$ ,144***). Again, when the results of the analysis were taken into consideration, it can be said that the Leadership Styles variable explains 10\% of Normative Commitment to Organization. It is seen that the H1b hypothesis is accepted as there is a significant relation between the Leadership Styles and Normative Commitment to Organization variables. $\mathrm{H} 1$ hypothesis was also accepted in this sense.

The second model deals with the relation of organizational citizenship behaviour variable with the employee performance variable. Table 4 includes the findings on the results of regression analysis of the second model. 
Journal of Global Strategic Management | V. 8 | N. 1 | 2014-June | isma.info | 57-68 | DOI: 10.20460/JGSM.2014815653

\section{Table 4. The Results of Regression Analysis of the Relation of Organizational Citizenship Behaviour Variable with the Employee Performance}

\begin{tabular}{|c|c|c|c|}
\hline & & \multicolumn{2}{|l|}{ DEPENDENT VARIABLE } \\
\hline & & \multicolumn{2}{|c|}{ Organizational Commitment } \\
\hline \multicolumn{2}{|l|}{ Independent Variable } & $\begin{array}{l}\text { Affective Commitment } \\
\text { to Organization }\end{array}$ & $\begin{array}{l}\text { Normative Commitment } \\
\text { to Organization }\end{array}$ \\
\hline \multirow{3}{*}{$\begin{array}{l}\text { Reasons of Employee } \\
\text { Silence }\end{array}$} & Managerial and Organizational Reasons &,$- 146 * *$ &,$- 223 * * *$ \\
\hline & Work Related Issues &,- 016 &, 055 \\
\hline & Lack of Experience &,$- 135 * *$ &, $173 * * *$ \\
\hline Leadership Styles & Fear of Isolation and Breaking Relations &,$- 112 *$ & 046 \\
\hline \multicolumn{2}{|l|}{$\mathrm{R}$} & ,343 &, 195 \\
\hline \multicolumn{2}{|l|}{$\mathrm{R}^{2}$} &, 118 & 038 \\
\hline \multicolumn{2}{|l|}{$\mathrm{F}$} & 25,131 & 7,445 \\
\hline \multicolumn{2}{|l|}{ Sig } & 0,000 & 0,000 \\
\hline
\end{tabular}

$* * * \mathrm{p}<0.001 ; * * \mathrm{p}<0.01 ; * \mathrm{p}<0.05$

When Table 4 is examined, a significant relation was found between the Reasons of Employee Silence and sub dimensions of Lack of Experience, Fear of Isolation and Breaking Relations and Affective Commitment to Organization $(\mathrm{R}=, 343, \mathrm{R} 2=, 118, \mathrm{~F}=25,131, \mathrm{p}<.001)$. The relation between the Managerial and Organizational Reasons and Affective Commitment to Organization was found negatively significant $\left(\beta=-, 146^{* *}\right)$, the relation between Work Related Issues and Affective Commitment to Organization was not found to be significant ( $\beta=$ ,016), relation between the Lack of Experience and Affective Commitment to Organization was found to be negatively significant $\left(\beta=-, 135^{* *}\right)$, Relation between Fear of Isolation and Breaking Relations and Affective Commitment to Organization was found to be negatively significant $(\beta=-, 112 *)$. Also, when the results of the analysis are taken into consideration, it can be said that the Reasons of Employee Silence variable explains 12\% of Affective Commitment to Organization. H2a hypothesis appears to be accepted as there is a significant relation between the Reasons of Employee Silence and Affective Commitment to Organization variables.

When Table 4 is examined, a significant relation was found between the Reasons of Employee Silence and sub dimensions of Lack of Experience, Fear of Isolation and Breaking Relations and Normative Commitment to Organization $(\mathrm{R}=, 195,343, \mathrm{R} 2=, 038, \mathrm{~F}=7,445, \mathrm{p}<.001)$. The relation between the Managerial and Organizational Reasons and Normative Commitment to Organization was found to be negatively significant ( $\beta=$ ,$\left.- 223^{* * *}\right)$, the relation between Work Related Issues and Normative Commitment to Organization was not found to be significant $(\beta=-, 055)$, relation between the Lack of Experience and Normative Commitment to Organization was found to be positively significant $\left(\beta=, 173^{* * *}\right)$, Relation between Fear of Isolation and Breaking Relations and Normative Commitment to Organization was not found to be significant $(\beta=, 046)$. Also when the analysis results were taken into consideration, it can be said that the Reasons of Employee Silence variable explains $4 \%$ of Normative Commitment to Organization. H2b hypothesis appears to be accepted as there is a significant relation between the Reasons of Employee Silence and Normative Commitment to Organization variables. $\mathrm{H} 2$ hypothesis is also accepted in this scope.

Third model deals with whether there is relation between Leadership Styles and Reasons of Employee Licence and Organizational Commitment variable. Table 5 includes findings on the regression analysis result of the first model. 
Journal of Global Strategic Management | V. 8 | N. 1 | 2014-June | isma.info | 57-68 | DOI: 10.20460/JGSM.2014815653

Table 5. Regression Analysis Results of Relation between Leadership Styles and Reasons of Employee Licence and Organizational Commitment variable

\begin{tabular}{|c|c|c|c|c|c|}
\hline & & & & Dependent Variable & \\
\hline Independen & ariable & & & Organizational Com & mitment (forming) \\
\hline & & $\begin{array}{l}\text { Affective } \\
\text { Commitment to } \\
\text { Organization }\end{array}$ & $\begin{array}{l}\text { Normative } \\
\text { Commitment to } \\
\text { Organization }\end{array}$ & $\begin{array}{l}\text { Affective } \\
\text { Commitment to } \\
\text { Organization }\end{array}$ & $\begin{array}{l}\text { Normative } \\
\text { Commitment to } \\
\text { Organization }\end{array}$ \\
\hline & \begin{tabular}{|l|} 
Transformative \\
Leadership \\
\end{tabular} & ,006 &, $353^{* * *}$ &,- 058 &, $346^{* * *}$ \\
\hline $\begin{array}{l}\text { Leadership } \\
\text { Styles }\end{array}$ & \begin{tabular}{|l|} 
Transactional \\
Leadership
\end{tabular} &,- 008 &,- 025 &, 025 &,- 024 \\
\hline & $\begin{array}{l}\text { Laissez-faire } \\
\text { Leadership }\end{array}$ &,$- 272 * * *$ &, $144 * * *$ &,$- 131 * *$ &, $088^{*}$ \\
\hline Reasons of & \begin{tabular}{|l|} 
Managerial and \\
Organizational \\
Reasons \\
\end{tabular} & & &,$- 124 *$ &,- 054 \\
\hline $\begin{array}{l}\text { Employee } \\
\text { Licence }\end{array}$ & Work Related Issues & & &,- 015 & 040 \\
\hline & Lack of Experience & & &,$- 109 *$ &, $111 * *$ \\
\hline & $\begin{array}{l}\text { Fear of Isolation and } \\
\text { Breaking Relations }\end{array}$ & & &,- 101 & ,047 \\
\hline $\mathrm{R}$ & & 276 & ,321 & ,359 & ,345 \\
\hline $\mathrm{R}^{2}$ & & ,076 & ,103 & , 129 &, 119 \\
\hline $\mathrm{F}$ & & 20,704 & 28,817 & 15,902 & 14,530 \\
\hline Sig & & 0,000 & 0,000 & 0.000 & 0.000 \\
\hline
\end{tabular}

$* * * \mathrm{p}<0.001 ; * * \mathrm{p}<0.01 ; * \mathrm{p}<0.05$

When Table 5 is examined within the scope of Affective Commitment to Organization, the first sub dimension of Organizational Commitment, it was found that the relation between the Transformative Leadership and Transactional Leadership among the sub dimensions of Leadership Styles and the Organizational Commitment is not significant, while the relation with Laissez-faire Leadership is negatively significant. It was found that the relation between the Managerial and Organizational Reasons and Lack of Experience, among the sub dimensions of Reasons of Employee Silence, and Organizational Commitment was negatively significant and there was no significant relation between the Work Related Issues and Fear of Isolation and Breaking Relations $(\mathrm{R}=, 359, \mathrm{R} 2=$ ,129, $\mathrm{F}=15,902, \mathrm{p}<.001)$. When Table 5 is examined within the scope of Normative Commitment to Organization, the second sub dimension of Organizational Commitment, it was found that the relation between the Transactional Leadership among the sub dimensions of Leadership Styles and the Organizational Commitment is not significant, while the relation with Transformative Leadership and Laissez-faire Leadership is positively significant. It was found that the relation between the Lack of Experience, among the sub dimensions of Reasons of Employee Silence, and Organizational Commitment was positively significant and there was no significant relation between the Managerial and Organizational Reasons, Work Related Issues and Fear of Isolation and Breaking Relations $(\mathrm{R}=, 345, \mathrm{R} 2=, 119, \mathrm{~F}=14,530, \mathrm{p}<.001)$.

It is seen within both sub dimensions of the Organizational Commitment variable that when Leadership Styles and Reasons of Employee Silence are included in the model together, contribution of Leadership Styles to model does not decrease and the contribution of Reasons of Employee Silence does not increase. In this case, it cannot be said that the Reasons of Employee Silence are intermediate (forming) variables between Leadership Styles and Organization Commitment. Therefore $\mathrm{H} 3$ hypothesis is rejected.

\section{DISCUSSION, RESULTS AND SUGGESTIONS}

It is found that there is a significant relation between Laissez-faire Leadership sub dimension of Leadership Styles and Affective Commitment to Organization. This is an expected result. Likewise, affective commitment which is stated as based on the voluntariness of employees (Mir etal. 2002) and the Laissez-faire Leadership that leaves right to use power totally to subordinates (Bass, 1990) are compliant within the framework of being able 
to use voluntariness-initiative. Here, affective commitment to organization is underlined within the framework of supporting organizational goals. The same situation is also seen between the Laissez-faire Leadership and Normative Commitment to Organization. Normative Commitment to Organization complies with the Normative commitment which follows the goal of becoming useful to the organization with the feeling of indebtedness (Herscovitch and Meyer, 2002) within the framework of Laissez-faire Leadership which allows appropriate work environment. It is seen that Transactional Leadership has no significant relation with neither Affective Commitment to Organization nor to Normative Commitment to Organization. No significant relation was found between Transformative Leadership and Affective Commitment to Organization, while there is a positively significant relation with the Normative Commitment to Organization. By its nature, Transformative Leadership chooses the way for the employees to work and have others work (Greenberg and Baron, 2000). The basis of employee voluntariness was previously mentioned. Non-compliance of concepts like voluntariness and having a job done is an expected result. On the other hand, loyalty taking place in the event that convenient work environment which is a part of Normative Commitment, is positively compliant with transformative leadership. Both situations can be expected.

The point to particularly focus here is addressing Organizational Commitment with the sub dimensions of emotional and normative commitment to the Organization itself. No such study was found in the literature. A study with the sub dimensions of Organizational Commitment as Affective and Normative Commitment to Superior shows that Transformative Leadership sub dimension has a positively significant relation with the sub dimension of Commitment to Superior (Zehir, Şehitoğlu and Erdoğan, 2010). However, in our study, Transformative Leadership has a positively significant relation with normative commitment to organization while it has no significant relation with affective commitment to organization. This situation is believed to be caused from the fact the Affective commitment is a behavioural phenomenon related to personality factors. Likewise, it is expected that personality qualities of employee cause more mutual relation with superior and it is similarly expected that it is not underlined in its commitment relation with the organization. It is believed that there may be a clearer analysis by including personality types of employees into these variables. It is recommended that future studies should include an evaluation of variables with personality types scale known as Big Five Personality Model in the literature.

The relation between Affective Commitment to Organization and sub dimensions of Reasons of Employee Silence namely Managerial and Organizational Reasons, Lack of Experience and Fear of Isolation and Breaking Relations was found to be significant. This is an expected situation. Reasons of Employee Silence cover the fact that all relations to be established would have a risk basically due to fear and lack of trust. Voluntariness and initiative taking actions of affective commitment have negative relation with the said reasons of Employee Silence in this scope. Normative Commitment emphasized with respect to support objectives may show itself in a work environment where lack of trust is removed, fear is eliminated and future risks are prevented. On the other hand, no significant relation was found between Affective Commitment to Organization and to Work Related Issues. It may be expected that Affective Commitment to Organization would be related to employee position in the workplace and removing the promotion concerns but our study did not find any significant relation between them. This is also experienced in the relation between the Work Related Issues and Normative Commitment to Organization. Here, the relation between the Normative Commitment to Organization and Lack of Experience sub dimension is expected to have a negatively significant relation. This may be the result of the conflict of being loyal to the employer which is underlined in Normative Commitment as the experience of employee within the organization increases. Here it is believed that there will not be an approach like "increase of experience would create loyalty" while it is intended and recommended to have further studies on the effect of the concept of loyalty on the employee silence.

In our study, intermediary (forming) effect of Reasons of Employee Silence on Leadership Styles and Organizational Commitment was studied and no intermediary effect was determined. Here, the basic problem is believed to be caused from the relation of affective commitment with work related factors and from the relation of normative commitment with social factors. This can also be caused from the emphasis of conscious, or conscientious in other words, behaviour roles of individual who have affective commitment. For further studies, it is intended and recommended to renew and expand the analysis by including the Organizational Citizenship Behaviour into the variables of our study. 


\section{REFERENCES}

Allen, N.J. and Meyer J.P. (1990), "The Measurement and Antecedents of Affective, Continuance and Normative Commitment to the Organization”. Journal of Occupational Psychology, 63 (118):1-18.

Amah, O.E., and Okafor, C.A. (2008). "Relationships Among Silence Climate Employee Silence Behaviour and Work Attitudes: The Role of Self- Esteem and Locus of Conrol". Asian Journal of Scientific Research, 1 (1): 1 11 .

Bass, Bernard M. (1990), “Bass \&Stogdill's Handbook Of Leadership.” The Free Press: New York.

Bass B.M. and Avolio B.J. (1994), "Improving Organizational Effectiveness, Through Transformational Leadership". SAGE Publications London

Becker T.E. and Billings R.S. (1993), "Profiles Of Commitment: An Empirical Test". Journal of Organizational Behavior, 14 (2):177-190.

Bodla, M.A. and Nawaz, M.M. (2010), "Transformational Leadership Style and its relationship with satisfaction”. Interdisciplinary Journal of Contemporary Research in Business, 2(1): 370-381.

Çakıcl, A. (2007), “Örgütlerde Sessizlik: Sessizliğin Teorik Temelleri ve Dinamikleri”, Ç.Ü. Sosyal Bilimler Enstitüsü Dergisi, 16 (1):145-162.

Dick, G. and Metcalfe B. (2001), "Managerial Factors and Organisational Commitment - A Comparative Study of Police Officers and Civilian Staff". International Journal of Public Sector Management, 14(2), 111-129.

Dimitras, B. and Vakola M. (2003), "Organisational Silence: A New Challenge for Human Resources Management". Retrieved August, 25, 2005.

Dubin R., Champoux J.E. and Porter L.W. (1975), "Central Life Interests and Organizational Commitment of Blue-Collar and Clerical Workers". Administrative Science Quarterly, 20 (3): 411-421.

Eren, Erol (2001), “Örgütsel Davranış ve Yönetim Psikolojisi”, 7. bası, Beta Basım, İstanbul.

Frazier P. A., Tix P. and Barron K. E. (2004), "Testing Moderator and Mediator Effects in Counseling Psychology Research”. Journal of Counseling Psychology, 51(1): 115-134.

Giri, V.N. and Santra, T. (2010), "Effects of Job Experience, Career Stage, and Hierarchy on Leadership Style". Singapore Management Review, 32 (1): 85-93.

Glad, B. and Blanton, R. (1997), "FW de Klerk and Nelson Mandela: A Study in Cooperative Transformational Leadership”. President Studies Quarterly, 27: 570-579.

Gordon, J.R. (1993), “A diagnostic approach to organizational behavior”. Allyn and Bacon (Boston), 4th edition.

Greenberg, J. and Baron, R. A. (2000), "Behavior in organizations” (7th ed.). Upper Saddle River, NJ: Prentice Hall.

Hambey L.A., O'Neill T.A. and Kline, T.J.B. (2007), "Virtual Team Leadership: The Effects Of Leadership Style And Communication Medium On Team Interaction Styles And Outcomes". Organizational Behavior and Human Decision Process. 103 (1): 1-20.

Herscovitch, L. and Meyer, J.P. (2002), "Commitment to Organizational Change: Extension of a ThreeComponent Model". Journal of Applied Psychology, 87 (3): 474-487.

Lather, A.S., Jain, V.K., Jain, S. and Vikas, S. (2009) "Leadership Styles in Relation to Conflict Resolution Modes : A Study of Delhi Jal Board (DJB)", XIMB Journal Of Management, 6 (1): 19-38.

Liao, S., Hu, D. and Chung, H. (2009), "The relationship between leader-member relations, job satisfaction and organizational commitment in international tourist hotels in Taiwan", The International Journal of Human Resource Management. 20 (8): 1810-1826. 
Journal of Global Strategic Management | V. 8 | N. 1 | 2014-June | isma.info | 57-68 | DOI: 10.20460/JGSM.2014815653

Lok, P. and Crawford, J. (1999), "The relationship between commitment and organizational culture, subculture, leadership style and job satisfaction in organizational change and development". Leadership \& Organization Development Journal, 20 (7):365 - 374.

Chiok Foong Loke, J. (2001), "Leadership Behaviours: Effects on Job Satisfaction, Productivity and Organizational Commitment". Journal of Nursing Management. 9 (4):191-204.

Mathieu, J.E. and Zajac, D.M. (1990) "A review and meta-analysis of the antecedents, correlates, and consequences of organizational commitment” Psychological Bulletin, 108 (2):171-194.

Meyer, J.P. and Allen, N.J. (1997), "Commitment in the workplace: theory, research and application”. Thousand Oaks, CA: Sage.

Meyer, J.P. and Herscovitch, L. (2001), "Commitment in the workplace: Toward a general model”. Human Resource Management Review, 11 (3): 299-326.

Meyer J.P., David J.S., Herscovitch L. and Topolnytsky L. (2002), “Affective, Continuance, and Normative Commitment To The Organization: A Meta-Analysis of Antecedents, Correlates, and Consequences”. Journal of Vocational Behavior 61 (1): 20-52.

Milliken, F.J., Morrison E.W. and Hewlin P.E. (2003), “An Exploratory Study of Employee Silence: Issues That Employees Don't Communicate Upward and Why” Journal of Management Studies. 40 (6): 1453-1476.

Mir, A., Mir, R., Mosca, R. and Joseph, B. (2002), “The New Age Employee: An Exploration of Changing Employee - Organization Relations", Public Personnel Management, 31 (2): 187-200.

Morrison E.W. and Milliken, F.J. (2000), "Organizational Silence: A Barrier to Change and Development in a Pluralistic”. The Academy of Management Review, 25 (4): 706 - 725.

Pillai R., Scandura T.A. and Williams E. A. (1999), "Leadership and Organizational Justice: Similarities and Differences across Culture” Journal of International Business Studies, 30 (4): 763-779.

Pinder, C.C. and Harlos K.P. (2001), "Quiescence and Acquiescence as Responses to Perceived Injustice”, Research in Personnel and Human Resources Management, 20: 331-369.

Premeaux, S. F. and Bedeian A.G. (2003), "Breaking The Silence:The Moderating Effects of Self-Monitoring in Predicting Speaking Up in The Workplace”. Journal of Management Studies 40 (6): 1537 - 1562.

Rowden R.W. (2000), "The Relationship Between Charismatic Leadership Behaviors and Organizational Commitment”. Leadership \& Organization Development Journal. 21 (1/2): 30-35.

Sosik, J.J. and. Godshalk V.M. (2000), "Leadership Styles, Mentoring Functions Received and Job Stress: A Conceptual Model and Preliminaryi Study”, Journal of Organizations Behavior, 21: 365-390.

Steers R.M. (1977), "Antecedents and Outcomes of Organizational Commitment”. Administrative Science Quarterly. 22 (1): 46-56.

Vakola, M. and Bouradas D. (2005), "Antecedents and Consequences of Organisational Silence: An Empirical Investigation”. Employee Relations, 27 (4/5):441 - 458.

Wasti S.A. and Can O.(2007) "Bağlllık Odakları: Örgüte, Amire Ve Çalışma Arkadaşlarına Bă̆lılık Ölçeklerinin Türkçe'de Geçerlemesi” XV. Ulusal Yönetim ve Organizasyon Kongresi Bildiriler Kitabı, 735-744.

Wasti S.A. and Can O.(2008) "Affective and Normative Commitment to Organization, Supervisor, and Coworkers: Do Collectivist Values Matter?”, Journal of Vocational Behavior 73 (3): 404-413.

Zehir, C.,Şehitoğlu Y. and Erdoğan, E. (2010). "The Effect of Leadership and Supervisory Commitment to Organizational Performance". 8th International Strategic Management Conference, Procedia - Social and Behavioral Sciences, 58 (12): 207-216. 